\title{
The Use of Trailer Film to Increase English Essay Writing of Higher Education Students
}

\author{
Euis Meinawati', Herlin Widasiwi Setianingrum², Sufi Alawiyah3, \\ Chodidjah4, Suwarsito5, Viviana Lisma Lestari6
}

DOI: 10.35445/alishlah.v13i3.1457

\begin{tabular}{|c|c|}
\hline Article Info & Abstract \\
\hline $\begin{array}{l}\text { Keywords: } \\
\text { English; } \\
\text { Essay; } \\
\text { Film; } \\
\text { Trailer; } \\
\text { Writing }\end{array}$ & $\begin{array}{l}\text { Essay writing has a fairly complex level of difficulty. Moreover, the online and } \\
\text { offline learning process in technological progress has directed learning activities } \\
\text { to be carried out through technological innovation. This study aimed to } \\
\text { determine the impact of film trailers on improving English essay writing skills } \\
\text { for students at a Private University in Jakarta. The research method uses } \\
\text { experiments with a one-group experimental design. 50 students were recruited } \\
\text { using a purposive sampling technique the study participants. The research was } \\
\text { conducted at the 3rd-semester students of the 2021-2022 academic year. The } \\
\text { data analysis techniques used were essay tests and observation. Data were } \\
\text { analyzed using t-test. The results show that students in the Essay Writing class } \\
\text { experienced an increase in their ability to write English essays. 80\% of the } \\
\text { respondents experienced an increase in their English essay writing test scores } \\
\text { before and after using the film trailer learning media. In addition, the data from } \\
\text { the t-test also showed that t-Stat < t-table (-10.384 < } 2.0095) \text {, meaning that } \\
\text { there was a significant effect of movie trailers on English essay writing skills. } \\
\text { The results of the study also have implications for the understanding of the } \\
\text { teaching staff regarding the use of digital learning media or technology } \\
\text { applications in building more innovative writing classes }\end{array}$ \\
\hline
\end{tabular}

Kata kunci:

Bahasa Inggris;

Esai;

Film;

Trailer;

Menulis

\begin{abstract}
Abstrak
Menulis esai mempunyai tingkat kesulitan yang cukup komplek. Apalagi proses pembelajaran daring dan luring di era kemajuan teknologi telah mengarahkan kegiatan pembelajaran harus dilakukan melalui inovasi teknologi. Tujuan penelitian ini adalah untuk mengetahui dampak dari trailer film untuk meningkatkan kemampuan menulis esai Bahasa Inggris bagi mahasiswa di Universitas swasta di Jakarta. Metode penelitian menggunakan ekperimen dengan one-group experimental design. Partisipan diambil menggunakan teknik purposive sampling sebanyak 5o mahasiswa. Penelitian dilakukan pada mahasiswa semester 3 tahun akademik 2021-2022. Teknik analisis data
\end{abstract}

\footnotetext{
${ }^{1}$ Universitas Bina Sarana Informatika Jakarta, Indonesia Email: euismei84@gmail.com

${ }^{2}$ Universitas Bina Sarana Informatika Jakarta, Indonesia Email: herlin.hww@bsi.ac.id

3 Universitas Bina Sarana Informatika Jakarta, Indonesia Email: sufi.sfy@bsi.ac.id

4 Universitas Bina Sarana Informatika Jakarta, Indonesia

Email: chodidjah.cdj@bsi.ac.id

5 Universitas Bina Sarana Informatika Jakarta, Indonesia

Email: suwarsito.swr@bsi.ac.id

${ }^{6}$ UIN Syarif Hidayatullah Jakarta, Indonesia

Email: Viviana.lisma@uinjkt.ac.id
} 


\begin{abstract}
menggunakan tes esai dan observasi. Data dianalisis menggunakan t-test. Hasil penelitian menunjukkan bahwa mahasiswa di kelas Essay Writing mengalami peningkatan kemampuan menulis esai Bahasa Inggris. Ada 80\% dari jumlah responden yang mengalami peningkatan nilai tes menulis esai Bahasa Inggris sebelum dan sesudah menggunakan media belajar trailer film. Selain itu, data hasil t-test juga menunjukkan bahwa t-Stat $<$ t-table $(-10.384<2.0095)$, artinya bahwa ada pengaruh signifikan dari trailer film pada keterampilan menulis esai Bahasa Inggris. Hasil penelitian juga berimplikasi pada pemahaman para tenaga pengajar terkait dengan pemanfaatan media belajar digital ataupun aplikasi teknologi dalam membangun kelas menulis yang lebih inovatif.
\end{abstract}

\title{
INTRODUCTION
}

Essay writing is one of the names of the courses in the English language study program at a private university in Jakarta which is given to the 3rd-semester students. This course is among the series of English writing skills given to students. However, learning English essays is not an easy thing for students. The results of the evaluation of learning activities during the Covid-19 pandemic for students in the third semester of the 2019/2020 and 2020/2021 academic years concluded that there was a decrease in student essay writing results compared to essay writing classes before the pandemic. Students who gave some inputs at the end of the semester also concluded that they needed technology media that could be used during zoom conferences in writing classes. Students needed idea stimulation to develop essays and arguments as reciprocal student writing (Wingate, 2012). Therefore, learning to write English essays requires a change in the use of learning media. To support online learning activities through zoom conference in English essay writing class, video media is one way to develop writing ideas (Umutlu, 2017), as YouTube can have an impact on the affordability of texts and play a positive role in the accuracy of English writing (Alobaid, 2021). Videos presented in various types impact student learning outcomes (Smith, 2014). Even Aryuntini et al. (2018) shows that Video Scribe-based learning media improve students' ability to write descriptive text in English subjects

From this explanation, learning to write English essays should be equipped with learning media by current developments, such as digital technology. The film can also be used as a medium to stimulate story ideas for students. Previous research has shown that videos (films) also positively impact writing skills. However, this study uses movie trailers taken from YouTube to learn to write English essays. This is because the film trailer shows a clear story of a film, but students have to interpret it before watching the full film. Thus, film trailers can stimulate students in developing story themes and critical thinking patterns in pouring all the information they have to compose paragraphs. Film trailers are also considered one of the multimedia technologies that can positively impact student progress. So far, many studies have shown the effectiveness or impact of multimedia technology on improving writing skills. Advances in technology have provided convenience in teaching and learning today. Especially in the era of the Covid-19 pandemic, online learning activities require technology media. So, teachers must have more innovative learning designs to accommodate online learning needs. Since this type of learning is challenging for both teachers and students, teachers should be able to put their role as facilitators to build more engagement with students and trigger students to be more independent in learning (Sariani et al., 2021). Even studies related to online learning activities, or blended learning have contributed to students' writing achievements (Gustiani et al., 2020; Sharadgah, 2014; Wahyuni, 2018). Students can use blogs as learning media in developing writing performance (Özdemir \& Aydın, 2015). Even social media has also been used for writing learning activities, such as Instagram (Akhiar, 2017). Thus, technology development provides convenience in creating a more creative online or offline learning environment and according to student needs.

Therefore, this study aimed to find out the impact of film trailers on English essay writing skills. Moreover, the era of technological progress and the Covid-19 pandemic has guided all lines of human life to involve technology. The results of this study are also expected to benefit teachers' 
understanding in determining the right multimedia technology according to the background and needs of students.

\section{METHOD}

\section{Method of Research}

The one-group experimental design was used in the study's experimental research. It is a pretest-posttest design with a single group. The one pretest and posttest design was a quasiexperimental research design in which the same dependent variable was measured in one participant group before the pretest and after the posttest treatment (Creswell \& Creswell, 2018). This study allows comparing students' English essay writing before and after using trailer film as learning media.

\section{Participants}

Participants were third-semester students in the academic year 2021-2022 ( $\mathrm{F}=23$ and $\mathrm{M}=27)$ at Private University in Jakarta. The criteria for participants are 1) aged between 18-21, 2) semester 3, and 3) getting the Essay Writing course. It was conducted from August until October 2021. Purposive sampling is used to collect the sample. The deliberate selection of informants based on their ability to explain a specific theme, concept, or phenomenon is known as purposeful sampling (Robinson, 2014). Thus, the sample used is students who have the criteria, namely taking essay writing courses, have received writing courses 1 and 2.

\section{Techniques for Collecting Data}

The process of collecting data was by using essay tests and observation.

a. The essay test is used to know students' English writing ability before and after using trailer films. The essay test used the following criteria: (1) organization (introduction, body and conclusion), (2) logical development of ideas, (3) grammar, (4) punctuation, spelling, and mechanics, and (5) styles and quality of expression. The score is taken between the range of 0-100.

b. Observation

While observation is used in the teaching and learning process to determine the students' learning progress.

\section{Data Analysis}

The t-test was used to compare the means of two samples. The formula application in Excel was used to calculate the t-test data analysis. It was used to determine the students' mastery of grammar learning.

\section{FINDING AND DISCUSSION}

The test data concluded that trailer film media could give an impact on English essay writing skills. The following is a comparison of pre-test and post-test scores for learning to write English essays using film trailers;

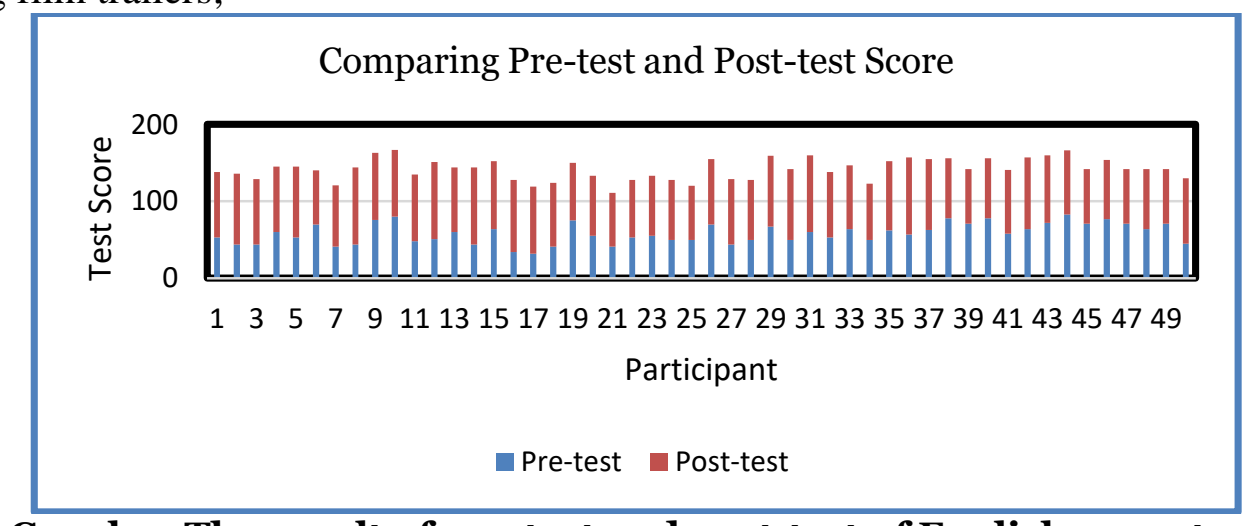

Graph 1. The result of pre-test and post-test of English essay test 
Graph 1 is the results of the essay tests (pre-test and post-test) and it was concluded that the film trailer had a positive impact and English essay writing skills also experienced a good change compared to the results of the English essay test before using the film trailer. From 50 students, it was found that $80 \%$ had improved their English essay writing skills. Data statistic descriptive showed the differences of pre-test and post-test results from essay writing test:

\begin{tabular}{lrr} 
Table 1. Statistic Descriptive Result of Pre-test and Post-Test \\
\cline { 2 - 3 } \multicolumn{1}{c}{ Statistic Data } & Pre-test & Post-test \\
\hline Mean & 58,22 & 83,84 \\
Standard Error & 1,826 & 1,2386 \\
Median & 57,5 & 85 \\
Mode & 44 & 85 \\
Standard Deviation & 12,916 & 8,7583 \\
Sample Variance & 166,828 & 76,7085 \\
Kurtosis & $-0,9057$ & $-0,689$ \\
Skewness & 0,0469 & 0,1677 \\
Range & 51 & 30 \\
Minimum & 32 & 70 \\
Maximum & 83 & 100 \\
Sum & 2911 & 4192 \\
Count & 50 & 50 \\
Confidence Level (95,0\%) & 3,67074 & 2,489 \\
\hline
\end{tabular}

Table 1 concludes that the mean value from pre-test to post-test increased by 25.62. The highest score in the pre-test was 83 and the post-test was 100 (perfect score) and this increase was 17 points. Meanwhile, the minimum pre-test score is 32 and the post-test score is 70 . Overall, from descriptive statistical data, it can be seen that movie trailers provide convenience for students in developing English essay writing skills. The results of the t-test for English essay writing skills are described in the following table;

Table 2. The result of t-test for English essay writing

\begin{tabular}{lrr}
\hline Mean & 58,22 & 83,84 \\
Variance & 166,82 & 76,708 \\
Observations & 50 & 50 \\
Pearson Correlation & $-0,26885$ & \\
Hypothesized Mean Difference & 0 & \\
df & 49 & \\
t Stat & $-10,384$ & \\
P(T<=t) one-tail & 2,837 & \\
t Critical one-tail & 1,676 & \\
P(T<=t) two-tail & 5,675 \\
t Critical two-tail & 2,0095 & \\
\hline
\end{tabular}

Table 2 gave the assumption $\mathrm{t}$-Stat $<\mathrm{t}$-table $(-10.384<2.0095)$. It can be said that Ho is rejected and $\mathrm{H}_{1}$ is accepted. It means that the trailer film positively impacted English essay writing skills.

Thus, it can be concluded from this finding that learning to write for university students leads to intellectual development and analytical power, according to scientific study. Students' abilities have been used to develop ideas and creativity to build ideas. So students write at the level of analysis and generate new ideas. At this level, students are product-oriented and process-oriented so that an integrated learning process occurs. It means that the writing process must also be carried out with the right approach, such as a genre-based approach that leads to the ability to write essays (Alabere 
\& Shapii, 2019). Writing is basically about how we can make sense, at the same time, a way for writers to participate in building new knowledge. When writing, the writer does two things, namely "telling knowledge" and "changing knowledge" so that it becomes knowledge. Of course, it takes a certain amount of knowledge and skills to make this happen. The ability to write English essays is related to the ability of students to assemble several paragraphs into writing that has many meanings.

About writing, students emphasized the importance of essays and academic works, describing, paraphrasing and producing complete academic writings. Students can use textbooks, references from the internet and journals as sources of information (Fatimah, 2019). Various sources become the most important part for students to develop their essay writing. The findings show that film trailers are a source of information for students in developing their ideas into essays. The story fragments in the film trailer teach and build students' critical thinking patterns to develop ideas or story pieces that are easier to develop. The selection of clips from films and TV series is deliberately chosen because it relates to different genres and is characterized by the use of the English language in specific domains (i.e., law, politics, economics, tourism, and medicine) (Bonsignori, 2018). So, multimedia technology is understood as a resource supporting the learning and teaching process.

Currently, video recordings in the form of film trailers are a part that impacts student performance (Reo \& Mercer, 2004). In addition, this media trailer can create a more different virtual learning environment. Moreover, the concept of a digital video-based learning environment can have a stronger effect than traditional face-to-face settings (Prilop et al., 2020). This is in line with (Colby, 2014) research which concludes that adding video games to writing courses opens up wider possibilities for considering how multimodal texts communicate rhetorically, in particular how the rules and game systems-procedures-offer additional modes of communication that engage writers to more actively considering how readers may interact with work. So, video can be judged to be the right medium for online learning activities. Videos are an essential component of most Massive Open Online Courses (MOOCs) and other forms of online learning. However, an assumption is that a video is a pedagogical tool, but media use is less explored, such as live video (Hansch et al., 2015).

Learners also often refer to streaming instructional videos for understanding concepts and theories as well as familiarizing themselves with the environment through simulations and virtual tours (Chan, 2010). Thus, this study shows the alignment concerning video and movie trailers. Basically, movie trailers also provide an interesting audiovisual concept and a series of stories to be conveyed in the film. However, the trailer only presents the main story snippets to understand the concept of the story. They can write the story into an interesting essay and develop it into a different story concept.

\section{CONCLUSION}

The findings conclude that film trailers are a fairly good choice of media for learning to write English essays. The results of the t-test showed an increase in the ability of English essay writing skills and the test scores also showed a significant change. Almost $80 \%$ of students have experienced changes in test scores before and after using the movie trailer. In addition, film trailers also make it easier for students to develop and be creative in making stories so that the results of their essays become more diverse. Moreover, online learning activities make the virtual environment more enjoyable. The study results also have implications for educators' understanding in determining digital or multimedia learning media for writing classes, both online and offline.

This research is still limited to learning media related to videos or films. Weaknesses were found to be related to the monitoring of online tests. Therefore, the results of this study can still be developed on the concept of implementing film trailers during studying or testing. In addition, the next researcher also relates to students' attitudes towards the use of multimedia technology. Using multimedia in learning in schools has many important factors in the stages of the technological revolution. 


\section{REFERENCES}

Akhiar, A. (2017). Students' perceptions and attitudes towards the use of Instagram in English language writing. Malaysian Journal of Learning and Instruction, 47-72. https://api.elsevier.com/content/abstract/scopus_id/85041138422

Alabere, R. A., \& Shapii, A. (2019). The Effects of Process-Genre Approach on Academic Writing. $\begin{array}{lllll}\text { JEES (Journal of English Educators Society), } & 4(2), & 89 .\end{array}$ https://doi.org/10.21070/JEES.V4I2.2598

Alobaid, A. (2021). ICT multimedia learning affordances: role and impact on ESL learners' writing accuracy development. Heliyon, $7(7)$.

Aryuntini, N., Astuti, I., \& Yuliana, Y. G. S. (2018). Development of Learning Media Based on VideoScribe to Improve Writing Skill for Descriptive Text of English Language Study. JETL (Journal Of Education, Teaching and Learning), 3(2), 187. https://doi.org/10.26737/jetl.v3i2.746

Bonsignori, V. (2018). Using films and TV series for ESP teaching: A multimodal perspective. System, 77, 58-69. https://doi.org/10.1016/J.SYSTEM.2018.01.005

Chan, Y. M. (2010). Video instructions as support for beyond classroom learning. Procedia - Social and Behavioral Sciences, 9, 1313-1318.

Colby, R. (2014). Writing and assessing procedural rhetoric in student-produced video games. Computers and Composition, 31(1), 43-52. https://doi.org/10.1016/j.compcom.2013.12.003

Creswell, J. W., \& Creswell, J. D. (2018). Research design: Qualitative, quantitative, and mixed methods approaches fifth edition. SAGE Publications Inc.

Fatimah, N. (2019). Students' Needs for Academic Writing at the English Education Department. In English Language Teaching Educational Journal (Vol. 1, Issue 3, p. 161). Universitas Ahmad Dahlan. https://doi.org/10.12928/eltej.v1i3.744

Gustiani, S., Sari, E. A., Yusri, \& Simanjuntak, T. (2020). The Effectiveness of Blended Learning Approach on Essay Writing Subject. 216-223. https://doi.org/10.2991/assehr.k.200407.037

Hansch, A., Hillers, L., McConachie, K., Newman, C., Schildhauer, T., \& Schmidt, P. (2015). Video and Online Learning: Critical Reflections and Findings from the Field. SSRN Electronic Journal. https://doi.org/10.2139/SSRN.2577882

Özdemir, E., \& Aydın, S. (2015). The Effects of Blogging on EFL Writing Achievement. Procedia Social and Behavioral Sciences, 199, 372-380. https://doi.org/10.1016/J.SBSPRO.2015.07.521

Prilop, C. N., Weber, K. E., \& Kleinknecht, M. (2020). Effects of digital video-based feedback environments on pre-service teachers' feedback competence. Computers in Human Behavior, 102, 120-131. https://doi.org/10.1016/j.chb.2019.08.011

Reo, J. A., \& Mercer, V. S. (2004). Effects of live, videotaped, or written instruction on learning an upper-extremity exercise program. Physical Therapy, 84(7), 622-633. https://doi.org/10.1093/ptj/84.7.622

Sariani, S., Khairat, M. El, \& Yaningsih, -. (2021). An Optimization of Language Learning in Writing Through E-Learning: Encountering Covid-19 Pandemic. International Journal of Language Education, 5(1), 528-541. https://doi.org/10.26858/IJOLE.V5I1.15375

Sharadgah, T. A. Al. (2014). Developing Critical Thinking Skills through Writing in an InternetBased Environment. International Journal of Humanities and Social Science2, 4(1).

Smith, D. K. (2014). iTube, YouTube, WeTube: Social Media Videos in Chemistry Education and

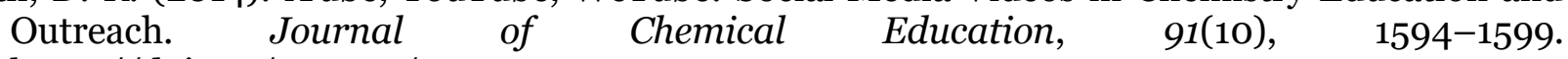
https://doi.org/10.1021/ED400715S

Umutlu, D. (2017). Effects of different video modalities in flipped english writing classes on students' writing scores. In New Trends and Issues Proceedings on Humanities and Social Sciences (Vol. 3, Issue 7, pp. 60-66). Birlesik Dunya Yenilik Arastirma ve Yayincilik Merkezi. https://doi.org/10.18844/prosoc.v2i7.1986

Wahyuni, F. A. (2018). BLENDED LEARNING: DUA METODE (SYNCHRONOUS AND ASYNCHRONOUS) UNTUK MATAKULIAH WRITING MATERI ARGUMENTATIVE ESSAY. In JINOTEP (Jurnal Inovasi dan Teknologi Pembelajaran): Kajian dan Riset Dalam Teknologi Pembelajaran (Vol. 3, Issue 2). https://doi.org/10.17977/UMo31V3I22017P137

Wingate, U. (2012). 'Argument!' helping students understand what essay writing is about. Journal of English for Academic Purposes, 11(2), 145-154. https://doi.org/10.1016/J.JEAP.2011.11.001 